\title{
Social Capital in Community Development at Prone Disaster Area: A Lesson Learnt at Sempu Village, Nglancar, Kediri, East Java, Indonesia
}

\author{
Windiani $^{1}$, Arfan Fahmi ${ }^{2}$, Zainul Muhibbin ${ }^{3}$
}

\begin{abstract}
This study aims to analyze the role of social capital in community development in disaster prone areas. The study was conducted in a disaster-prone area of Mount Kelud, Sempu Village, Ngancar District, Kediri Regency after the eruption in 2014. The study used a qualitative method with an ethnographic approach. The results showed that after the eruption in 2014, social capital in the community became a source of strength in community development in the Mount Kelud disaster-prone areas, especially in the process of restoring the social and economic life of the Sempu village community. Social ties, trusts, social networks that are strongly intertwined are the elements of social capital that are still strong which are found in the study area. The results of the study also found a responsive, innovative and transparent leadership pattern developed by the Village Head helped accelerate the recovery process of the socio-economic life of the Sempu village community. The results of the study also revealed that the social capital owned by the local community was tested for strength when dealing with external forces such as the presence of institutions and volunteers involved in the recovery process. This situation triggered tensions between residents and the apparatus assigned to distribute aid.
\end{abstract}

Keywords: Social Capital, Community Development, Disaster Prone Region

\section{INTRODUCTION}

Indonesia is a country that has a high level of natural disaster vulnerability. Based on 2018 World Risk Report data, Indonesia ranks 36 th with a risk index of 10,36 out of 172 countries most prone to natural disasters in the world. (World Risk Report , 2018) This is caused by the existence of tectonic Indonesia which is the meeting place of three tectonic plates of the world (Eurasia, IndoAustralia and Pacific), and volcanically as an active volcano track known as the Pacific Ring of Fire. This condition causes Indonesian territory to experience natural disasters such as earthquakes, tsunamis and volcanoes.

The National Disaster Management Agency (BNPB) noted, throughout 2018 Indonesia experienced many disasters caused by natural factors such as tsunamis, volcanic eruptions, and landslides. As of November 2018, 2,308 natural disasters had been recorded, causing

\footnotetext{
1,2,3 Windiani, Arfan Fahmi, and Zainul Muhibbin, Department of Development Studies, Fakulty of Business and Management Technology, Institut Teknologi Sepuluh Nopember, Surabaya, Indonesia Email: windiani@gmail.com, arfanfahi.its@gmail.com, zmuhib@gmail.com
}

4,201 people to die and disappear, while 9,883,780 were affected and displaced. Natural disasters also damaged 371,625 houses (BNPB, 2018). Moreover, Indonesia's geographical position in areas prone to natural disasters (ring of fire) also causes the Indonesian state to suffer billions of losses annually and impact on the national economy. According to Minister of Finance Sri Mulyani (2019) losses from natural disasters reach Rp. 22.8 trillion per year, Losses due to natural disasters are increasing every year, making the State Budget (APBN) also increase for repairs due to natural disasters (BNPB 2018).

In East Java Province, almost all of them are disasterprone areas. Based on data reported by the Regional Disaster Management Agency of East Java Province (2016), 32 of the 38 regencies are included in areas prone to floods, landslides, earthquakes and tsunamis, plus 7 active volcanoes in East Java, which at any time increased in activity, namely Mount Kelud in Kabupaten Kediri-Blitar-Malang, -Batu, Mount Arjuno-Welirang in Malang, Mount Bromo in Probolinggo, Mount Semeru in Lumajang, Mount Ijen in Banyuwangi, Mount Raung in Jember, and Mount Lemongan in Lumajang (BPBDJatim, 2016).

Kediri Regency is one of the disaster-prone areas in East Java with the potential threat of natural disasters including floods, landslides, tornadoes and volcanic eruptions. Based on data compiled from the Indonesian Disaster Information Data (DIBI) one of the most obvious potential threats is the eruption of Mount Kelud. As noted in Table 1, the eruption of Mount Kelud that occurred on February 13, 2014 caused 3,019 people to be displaced and 8,622 housing units were severely damaged.(BNPB, 2018).

After the eruption in 2014, the government through the Geological Agency of the Ministry of Energy and Human Resources (June, 2014) established a disasterprone area in the Kelud Mountain area covering three administrative regions namely Kediri, Blitar and Malang Regency. Mount Kelud disaster-prone areas are divided into three levels: the Mount Kelud Eruption Area (KRB) eruption, namely Disaster Prone Areas (KRB) III, Disaster Prone Areas (KRB) II, and Disaster Prone Areas (KRB) I (www.vsi.esdm.go.id, 2014).

Disaster-Prone Areas III, is an area that has the potential to be affected by eruptions, hot clouds, catapults, toxic gases and possible lava flows. KRB III covers an area of $14.36 \mathrm{~km} 2$ (1,436 ha). Disaster-Prone 
Areas II, is an area potentially affected by hot clouds, lava eruptions, lava flows, lightning stones and heavy ash rain. This area is predicted to cover an area of $91.8 \mathrm{~km} 2(9,180$ ha). The Disaster-Prone Zone I (KRB I), which is located a radius of 15 kilometers from the summit of Mount Kelud, with an area of $351 \mathrm{~km} 2$ (35,100 ha). This area has the potential to be exposed to rain lava and possibly lava eruption, potentially exposed to ash rain and may be hit by a stone throw (incandescent) (http://jatim.antaranew.com, 2019).

Sempu Village, Ngancar District, Kediri Regency, is one of the villages in the volcanic hazard-prone region (KRB) III, an area located within a $10 \mathrm{~km}$ radius of Mount Kelud. After the 2014 Kelud eruption, the awareness that living in disaster-prone areas does not mean that villages become powerless. This has become a motivation for Sempu Village to raise awareness and empower the community in facing disasters. One of the efforts carried out includes community development by forming a disaster resilient Village Sempu or Destana. For this effort, in 2019 the Government of Kediri Regency decided 4 villages in Kediri Regency, one of them was Sempu Village, Ngancar District, and 3 other villages namely Kebonrejo Village Kepung District, Kelipang Village Grogol District and Joho Village Wates District as disaster resilient areas. According to the Acting Head of the BPBD Kediri Regency Randy Agatha (Wednesday 4 April 2019), the establishment of Destana in the region of Kediri was based on regional priorities with high potential threats, followed by enthusiasm from the village government and public awareness of potential disaster threats [2].

This effort is certainly not easy to do without the involvement of various parties, especially the role of local institutions (Village Government) and the Sempu Village community as the main stakeholders. Determination as a disaster resilient area is a very important point for the people of Sempu Village. This indicates that the people of Sempu Village are able to organize their resources despite living in disaster prone areas. The existence of optimization of resources by the Sempu community also explains that the Sempu community can make good use of the capital they have in managing disaster prone areas. Capital owned by someone in the management of disaster-prone areas in the end is very influential for self-development and society as a whole. This is what underlies researchers to analyze and explore more deeply how social capital plays a role in community development and what elements of social capital are sources of strength in community development in disaster prone areas.

\section{THEORETICAL FRAMEWORK}

Community development is commonly conceived of as an effort to make changes for the better based on certain values. In this paper community development activities are discussed in the context of community life recovery after being hit by disasters related to the Mount Kelud eruption in 2014. Community development in the context of post-disaster recovery may have different characteristics from community development activities that are not related to disasters. In this research, the researcher intends to find out how the people of Sempu Village, Ngancar District, Kediri Regency utilize their capital in community development practices in the Mount Kelud disaster prone area and its implementation in utilizing capital for the recovery of post-eruption life in 2014. From several theorists about social capital such as James Coleman (1998), Robert Putnam (2006), Fukuyama (2007), and Pierre Bourdieu (1986), in this paper, researchers use social capital theory from Pierre Bourdieu.

Pierre Bourdieu (1979), in his book "La Distingtion" distinguishes three forms of capital namely economic capital, cultural capital, and social capital. Bourdieu defines social capital as "the aggregate of the actual or potential resources which are linked to possession of a durable network of more or less institutionalised relationships of mutual acquaintance and recognition." According to Bourdieu (1992) social capital is the overall actual and potential associated with ownership of a fixed network of institutional relationships based on mutual recognition and mutual recognition, in other words, by being a member of a group (the realm) people will get support from the capital owned collectively. [3].

James Coleman (1988) argues that social capital by function is "a variety of entities with two elements in common: they are all consist of some aspects of social structure, and they facilitate certain actions of actors ... within the structure". Coleman said that social capital facilitates individual and group activities developed by a network of relationships, reciprocity, trust and social norms. Social capital, in his view, is a neutral resource that facilitates every activity where society can become better and dependent on the use of social capital by each individual. (Coleman, 2011).

While Robert Putnam (2006) defines social capital as "the collective value of all" social networks "and the inclinations that arise from these networks to do things for each other". He believes social capital can be measured by the amount of trust and reciprocity in a society or between individuals. In addition, the concept of social capital has a more approach to the individual element. Investment in social relations is associated with the expectation of obtaining profits from the market. Fukuyama (2007) in the work "The Social Capital and Development: The Coming Agenda", states that social capital is a precondition for successful development. In this case the laws and political institutions become the main things in building social capital. The reason is strong social capital become a basic requirement in achieving strong economic and political growth Fukuyama emphasizes the importance of social capital based on trust (trust). In daily life, people interact with strong social capital as indicated by an atmosphere of mutual trust between citizens. This form of capital has close relations with achieving the level of welfare of the community or nation (Fukuyama, 2007) Furthermore, to dissect the problems examined in research in the context of community development in disaster prone areas, researchers used the concept of social capital from Pierre Bourdieu.

According to Bourdieu (1997) the amount of social capital owned by a member of a group depends on how 
far the quantity and quality of the network of relationships that can be created, and how much volume of economic, cultural and social capital owned by everyone in the network of relationships. In its development Bourdieu's works on social capital became part of a broader analysis of the various foundations of social order. Bourdieu's view in seeing the position of actors is explained Haryatmoko (2016: 45) in his work "Dismantling the Certainty Regime" in which Bourdieu sees the position of actors in the social arena is determined by the amount and weight of the capital they have, and by certain strategies they carry out to achieve their goals. The concept of social capital according to Pierre Bourdieu refers to the dependence between various kinds of other capital resources and as embedded in economic capital and social capital in relation to social theory [4].

In Bourdieu's thinking about social capital as described previously revealed that the position of actors in the field is determined by the amount and relative weight of the capital they have. Modallah that allows people to control their own destiny and the fate of others. Based on this it can be said that the capital owned by an individual influences and is affected by the network in a realm. The network position of individuals in a group plays an important role, because with this network the distribution of their capital can be conveyed. Social capital is indeed used by individuals to fight for their respective interests in a domain group, but if without a network. That capital also will not mean anything.

Furthermore, Bourdieu describes what capital is spread in the social sphere (Fashri: 2014: 109). According to Bourdieu, capital is categorized into 4 (four) types namely; First, economic capital includes the means of production (machinery, land), materials (income and objects) and money used for all purposes and passed down from generation to generation. Second, cultural capital is the overall intellectual qualification produced through formal education and family heritage. Third, social capital refers to social networks owned by actors (individuals or groups) in relation to other parties who have power. Fourth, all forms of prestige, status, authority, and legitimacy are accumulated as a form of symbolic capital. Furthermore, the characteristics of these forms of capital can be exchanged with one another. Dynamic capital movement indicates that capital can increase or decrease. The greater a person accumulates certain capital, the greater the opportunity to convert between capital.[5].

Capital is an asset that is owned by individuals or groups that can be used to determine its position in a domain. Capital must always be produced and reproduced again. Such is the case with the situation in the Sempu village community. In the context of community development in the Mount Kelud disasterprone area, the capital owned by the community is used as a source of strength to develop themselves, especially in the recovery process after the eruption in 2014. Implementation of the utilization of social capital in the recovery and development of the community of Sempu Village. type of capital from Pierre Bourdieu.

\section{RESEARCH METHOD}

This type of research is a qualitative study using an ethnographic approach to explore empirical data in the study area (Windiani and Rahmati 2016). The research was carried out in the Mount Kelud disaster prone area, Sempu Village, Ngancar District, Kediri Regency. Data collection was carried out using participant obeservation methods, document tracking and in depth interviews with research informants selected purposively according to the research objectives. Informants in the study include; Head of Sempu Village, Head of BPBD, Coordinator and Volunteers from the local community in Sempu Village and residents who live around Mount Kelud. Data processing is done by classifying and categorizing data based on several themes based on research focus. To test the validity of the data, researchers used source triangulation techniques. Data obtained from one source then researchers compare with other different sources. In the data analysis it is done descriptively-analytically.

This type of research is a qualitative study using an ethnographic approach to explore empirical data in the study area [6]. The research was carried out in the Mount Kelud disaster prone area, Sempu Village, Ngancar District, Kediri Regency. Data collection was carried out using participant obeservation methods, document tracking and in depth interviews with research informants selected purposively according to the research objectives. Informants in the study include; Head of Sempu Village, Head of BPBD, Coordinator and Volunteers from the local community in Sempu Village and residents who live around Mount Kelud. Data processing is done by classifying and categorizing data based on several themes based on research focus. To test the validity of the data, researchers used source triangulation techniques. Data obtained from one source then researchers compare with other different sources. In the data analysis it is done descriptively-analytically.[7].

\section{RESULTS AND DISCUSSION}

Sempu Village is one of the villages in the Kediri Regency which is the easternmost of the Ngancar District and is located in the highlands with an altitude of 500 $600 \mathrm{M}$ above sea level. Based on data obtained through the Village Information System (SID), administratively, the Sempu Village region has a northern boundary bordering with Sugihwaras Village, Ngancar District, in the south bordering Sumberasri Village, Nglegok Blitar District, in the east bordering Perhutani and in the West bordering Manggis Village, Ngancar District. (SID, Sempu 2017).

The Sempu Village area has an area of around $260 \mathrm{Ha}$ (3.7 km2) consisting of $40 \%$ in the form of settlements, $60 \%$ in the form of land used for agricultural land and is dominated by agricultural activities in tegal land (Ladang), namely Sugar Cane, Pineapple, Ketela, Horticulture and as the mainstay of community income is as a cenggkih farmer. The distance from the village center to the regency capital that can be reached by land travel is approximately $45 \mathrm{~km}$ and the travel time using a motor vehicle reaches approximately 60 minutes. While the distance from the village center to the capital of the sub- 
district is $7 \mathrm{Km}$, the travel time using a motorized vehicle reaches approximately 15 minutes.

The location of Sempu Village is located at an altitude of $\pm 600 \mathrm{~m}$ above sea level with an area of $247,748 \mathrm{Ha}$ is a mountainous area and the majority of the occupation of the population is pineapple farmers. The location of Sempu Village is very strategic because it is located at the end of the subdistrict capital so that pineapple farming which is the largest source of income for the Sempu Village community because the majority of Sempu villagers are pineapple farmers. Sempu Village consists of three hamlets: Sempu I Hamlet, Ringinsari II Hamlet and Sumberpetung Hamlet III with the number of RT 21 and RW 6.

Based on data obtained from Sempu village monographs and from the Village Information System (SID) as presented in table 1 . The number of Sempu villagers up to 2017 reached 3,531 inhabitants consisting of 1,791 inhabitants of male population and 1,740 of female population lives with 1272 families in the Sempu village.

Community development in vulnerable areas in Sempu Village is inseparable from the habitus that lives and develops in communities in the Kelud Mountain area. Life experience as a community that lives in the Kelud Mountain area on the one hand brings blessing to life with very fertile agricultural land conditions, but on the other hand the community must be prepared to live together with the risk of volcanic threats at any time of eruption. The process has an internalized and externalized value which then settles into a way of thinking and behavior patterns that are lived by the community as residents who live in disaster-prone areas of Mount Kelud, which mostly work as farmers. These characteristics also contributed to community development in the Mount Kelud disaster-prone areas after the 2014 eruption, especially in Sempu village, Ngancar District, Kediri Regency.

Sempu village, as one of the disaster-prone areas in Kediri district, became the field of struggle for Sempu villagers to rise and develop after Mount Kelud erupted in 2014. As a domain of struggle as initiated by Bourdieu (1986), the disaster-prone area of Sempu Village must able to become a place where the meeting of habitus and capital for residents of Sempu community. Communities may have different capital and habitus because of diverse backgrounds. However, in the efforts to restore and develop the community after the eruption of Mount Kelud in 2014, the Sempu village government together with the community members played their respective roles with their habitus and capital so that they were able to carry out their structured functions in community life.

In the efforts to restore and develop the community, social capital and cultural capital play a large role in the source of power for the people of Sempu Village. After the eruption in 2014, the Village Government as a local institution seeks to utilize its capital for the recovery of people's lives. The village government together with the community worked together, developing their knowledge and skills to utilize the local potentials that exist around Mount Kelud into a unique and distinctive tourist destination. Along with the recovery process with the construction of road infrastructure and improvement of public facilities, starting in 2017 the government of Sempu Village together with residents utilizes their abilities such as craft skills, developing orchid plantations, honey processing and development of pineapple fruit agricultural products optimized to be social capital in developing superior products Tourism villages are Anggrek Village, Indian Village and Pineapple Village.
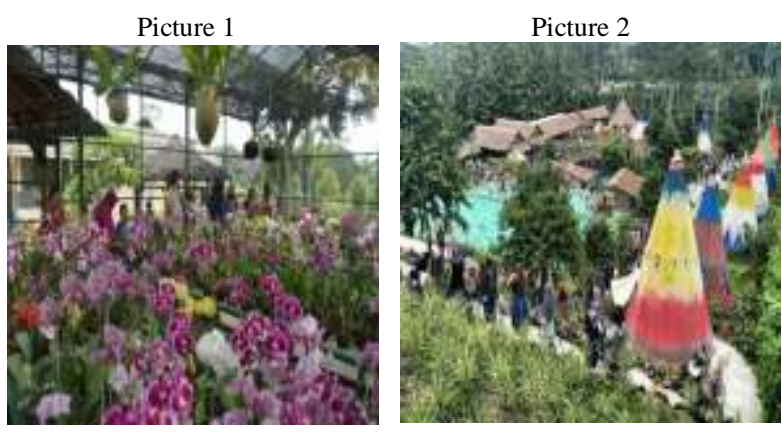

Picture 1 and 2. For economic recovery and community development after the eruption of Mount Kelud in 2014, Sempu Village developed the tourism villages 'Kampoeng Anggrek' and 'Kampung Indian' Source, SID Desa Sempu, 2018.

In the process of transformation and adaptation of communities in disaster-prone areas, especially the community of Sempu Village, it is very much determined by the basis of their social capital. historical experience, and different cultures. The basis of social capital owned by the Sempu village community living in the Mount Kelud disaster-prone areas can affect the needs and cognitive abilities of the local community. Different experiences of disaster history create different responses and this affects their perception of disaster-prone areas.

The results of research in the field, found that the people of Sempu Village, there was a very high awareness about disaster anticipation. This is based on past experience, with the number of victims when Mount Kelud erupted in 1990, the process of adopting information technology and new technology to anticipate disasters was quickly accepted by the public. Public facilities such as evacuation routes, refugee barracks and observation posts from the government and outsiders are well organized. Adaptation that occurs not only comes from the influence of outside parties, but from the Sempu community itself born and driven through local culture such as traditional ceremonies, rituals as a form of cultural response to the natural state of the environment. This kind of response occurs because the Sempu people's trust in the "Kelud ruler" is still a spirituality of their lives to be able to survive in areas prone to volcanic disasters. It cannot be denied that these rituals also support tour activities which in turn increase social, cultural and economic capital of the community.

The process of adaptation of the people of Sempu Village to nature and the environment today also adopts a lot of technology, especially in the development of tourism and agriculture which are the basis of today's economic support. As an area with high vulnerability, the people and government of Sempu Village utilize the social capital they have to open space for the growth of 
local communities and community organizations that support community development in disaster prone areas. Based on the results of exploration in the field, various organizations that grow and develop include Community Farmers Groups (Poktan), Village Disaster Preparedness Team (Tagana), Jaranan Krido Manggolo Art Group, Village Information Systems (SID) as shown in table 2. This community formed as a manifestation of relations with outsiders such as the Kelud Anchor Community, BPBD Regency and faith-based communities such as NU, Muhammdiyah, Christianity, Hinduism and Kejawen. This shows that the community and the government of Sempu Village are connected to the vast outside world which then forms a network and knowledge system which in turn becomes social capital for the community to strengthen social bonds between its members.

TABLE 2. THE LIST OF COMMUNITY GROUP AT SEMPU

\begin{tabular}{|c|c|c|c|}
\hline \multicolumn{4}{|c|}{ VILLAGE } \\
\hline No & $\begin{array}{c}\text { Nama } \\
\text { Kelompok/Komunitas }\end{array}$ & $\begin{array}{l}\text { Nama } \\
\text { Ketua }\end{array}$ & Alamat \\
\hline 1 & $\begin{array}{l}\text { Sumber Rejeki Farmers } \\
\text { Group }\end{array}$ & Sugianto & Sub-village Sempu \\
\hline 2 & Maju Farmers Group & Syamsiantc & Sub-village Ringinsari \\
\hline 3 & Sri Rejeki Farmers Group & Suyitno & $\begin{array}{l}\text { Sub-village } \\
\text { Sumberpetung }\end{array}$ \\
\hline 4 & $\begin{array}{l}\text { Subur Makmur Farmers } \\
\text { Group }\end{array}$ & Sukardi & Sub-village Sempu \\
\hline 5 & $\begin{array}{l}\text { Jaranan Community Krido } \\
\text { Manggolo }\end{array}$ & Soiman & Sub-village Sempu \\
\hline 6 & $\begin{array}{l}\text { Purbo Asmoro } \\
\text { Community }\end{array}$ & Kasbolah & $\begin{array}{l}\text { Sub-village } \\
\text { Sumberpetung }\end{array}$ \\
\hline 7 & $\begin{array}{l}\text { Village Alert Team } \\
\text { (Tagana Desa) }\end{array}$ & Sugito & Sub-village Ringinsari \\
\hline 8 & $\begin{array}{l}\text { Village Information } \\
\text { System Team (SID) }\end{array}$ & Wijianto & Sub-village Ringinsari \\
\hline
\end{tabular}

The Javanese culture of the Sempu community still feels thick coloring the daily lives of village people who are not just abandoned even though there is progress and development of information technology. Even the roots of Javanese culture are actually utilized and used as a glue for the people of Sempu Village to remain harmonious. This has proven to be the strength of a culture-based community, a faith-based community and other communities developing and becoming a cultural capital that is preserved by the Sempu Village community and becoming one of the main capital for the sustainability of community networks. On the other hand, Javanese tradition has an important role for the creation of the same interests to live and survive on the slopes of Mount Kelud which is divided into three hamlets namely Sempu Hamlet, Ringinsari Hamlet and Sumberpetung Hamlet.

Under normal conditions, (the situation does not occur), people in the Kelud Mountain area have high wisdom such as holding religious rituals collectively to hone inner sensitivity and build a bond of togetherness. Religious rituals or hamlet salvation, which are carried out collectively to obtain safety and various instructions, so that the hamlet is protected from disaster. Since 2007, people in the Kelud Mountain area, supported by the local government, have always held annual rituals. Besides aiming for the ritual of safety, and as a form of gratitude for the blessings given while living side by side with the
Kelud volcano, it also functions as a cultural mitigation and caring for social memories (memorial collective) of potential threats that can endanger the lives of residents living on the slopes of Kelud. Potential threats are not only primary threats due to volcanic material during eruptions, but also secondary threats such as floods and landslides due to rain lava, and exposure to poisons that can come at any time that requires vigilance and alertness of residents living on the slopes of Kelud.

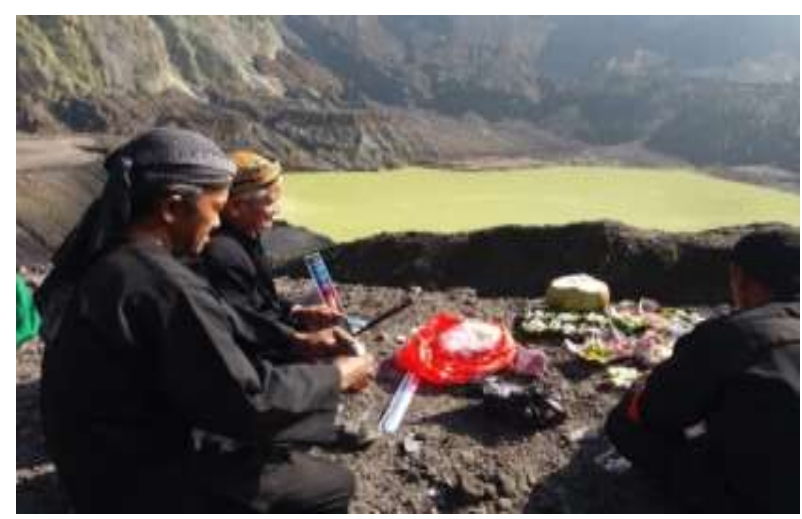

Picture 2: Larung Sesaji ritual in the crater of Mount Kelud every month Syuro, coincides September 20, 2017 AD, Source, Researcher Documentation, 2017

In post-disaster situations, various reconstruction and rehabilitation programs are strongly supported by the existence of social capital from residents. Infrastructure development such as roads and drinking water and housing use utilizes mutual cooperation so that even if residents do not receive assistance, they can own or repair damaged houses. In Sempu, Ngancar District, Kediri Regency, residents used living and other assistance to build houses, and mutual cooperation became a mainstay in the midst of them not being allowed to rebuild their homes back to their villages which were very susceptible to hot clouds. The strong social capital after the 2014 Kelud eruption and the readiness of the community in dealing with the impact of the eruption if Kelud 'has gawe' at the time, has made the social ties stronger.

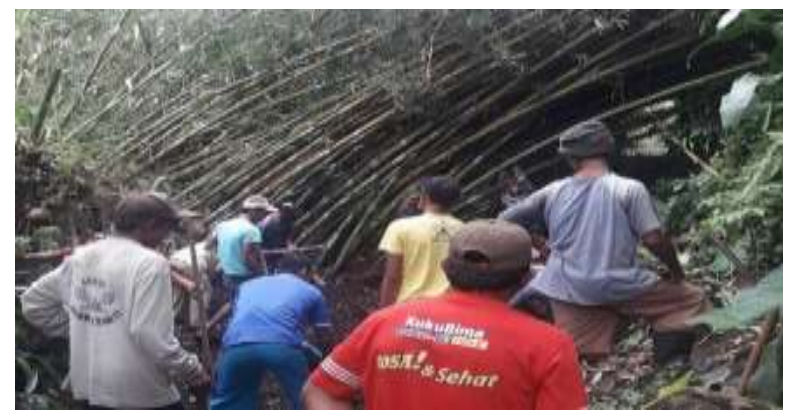

Picture 3. Social Capital: Mutual Assistance of Sempu Villagers. As one of the villages in the Mount Kelud disaster-prone area, the Sempu village government seeks to create the Sempu Village area into a disaster-safe area. Source: SID Desa Sempu, 2017.

In addition to collective rituals, residents of the Kelud slopes are also actively working together to build their hamlet infrastructure so that they can live well and have good roads for evacuation needs. The residents of the 
Kelud slopes are accustomed to building infrastructure such as roads and waterways using the strength of mutual cooperation and self-help so that this tradition becomes an important capital in the reconstruction phase. With mutual assistance and self-help, residents of Kelud slopes can overcome access to transportation and distribution of logistical assistance due to the impact of 2014.

By cooperating together, conducting joint rituals further strengthens social solidarity (bonding), and social ties between residents and village government. Efforts made by local institutions in the Kelud mountain area after the 2014 eruption are a form of social capital utilization especially for the development of communities in disaster prone areas. In addition, it is also a social capital in the development of local communitybased disaster mitigation that can be a source of strength for people in the Mount Kelud disaster-prone areas, especially in Sempu Village, Ngancar District, Kediri Regency.

The success of the Sempu Village community in the recovery and development of the community after the Mount Kelud eruption in 2014 is inseparable from the role of local leaders, especially the Sempu Village Head Mr. Eko Suroso, S.Pd. The results of the study found that the leadership patterns applied were more responsive, innovative and transparent developed by the Village Head, Mr. Eko Suroso, S.Pd, helped accelerate the process of restoring the social and economic life of the people of Sempu Village. Under his leadership, innovation in community development began in 2016. The Government of Sempu Village allocated the Resilient Village Pilot Program, which began by giving special attention to community-based disaster risk reduction efforts. In the plan to use Village funds for the 2016 Fiscal Year the Sempu village government developed a Capacity strengthening program for the Desa Siaga Team by allocating the use of village funds which included funding for capacity building activities for the Desa Siaga Team members, conducting preparedness training to deal with the threat of disasters that could occur at any time. Training activities in communitybased disaster risk reduction management and PPGD training for ordinary people are among the activities including planning the preparation of the Map of Disasters in Sempu Village and their evacuation routes when the disaster occurs. Besides that, the addition of preparedness facilities in the form of HT radio was also included in the planned allocation of the Pioneering Village Resilient Village program in the 2016 Budget Year (In-Dept Interview Results with Mr. Eko Suroso, Kades Sempu, 2018)

In addition to the Village Standby Team, the Village Information System Team, which manages data and information systems in the village was also developed by the Sempu village government, the Village Information System which was a pilot and pilot of the Kediri Regency BPBD project and UNDP was launched in 2015. This system has become the basis data that is very useful for community development in disaster prone areas, especially for preparing accurate population information data systems that can be used at any time and if a disaster can be utilized. The efforts of the Sempu Village government in pioneering and developing this DisasterResilient Village have been successful and since 2018 the Sempu Village has been designated a Disaster-Resilient Village by BPBD Kediri District and is one of the villages that is ready in various aspects to participate. (Sistem Informasi Desa (SID), Sempu, 2018).

The effort made by the Sempu Village Government by building cooperation and synergy with various parties such as the district government, NGOs, and the private sector has become an institutional social capital that is of great benefit for community development in disaster prone areas. Nevertheless, according to the information of one informant (Bp CS), the very strong social capital owned by the community was tested for its strength when facing a catastrophic situation, namely during the eruption of Mount Kelud in 2014. Strong social ties and solidarity, the harmony got ripped apart when faced with with external forces such as the presence of humanitarian agencies (NGOs) and volunteers involved mainly in the emergency response process, namely the distribution of logistical assistance and assistance for housing repairs during the recovery and rehabilitation process. This situation can trigger tensions between residents and the authorities in charge of distributing aid. In such situations, the involvement and capacity of local leaders such as the Village Head, religious leaders and community leaders are crucial in social control.

\section{CONCLUSION}

Indonesia is a country that has a high enough vulnerability to natural disasters. For this reason, the existence and role of social capital in community development practices in disaster prone areas is urgently needed. Social capital that lives and develops in the community can be a source of strength for people who live in disaster-prone areas. When disaster strikes, social ties, solidarity, social networks and trust (trust) and various forms of local wisdom (local habits and knowledge) are elements of social capital that are needed to survive. Likewise in the recovery process of the socioeconomic life of the community, social capital that manifests in the form of mutual cooperation, mutual harmony, community relations and local communities can help accelerate community revival and become a major capital in community development in disaster prone areas.

\section{REFERENCES}

[1] W. R. Report, "No Title," 2018.

[2] CNBC, "CNBC-Daerah Rawan Bencana," 2019.

[3] P. Bourdieu, Distinction, 2nd ed. London: London University Press, 1986.

[4] Haryatmoko, Membongkar Rezim Kepastian: Pemikiran kritis Post-Strukturalis. Yogyakarta: Kanisius, 2016.

[5] F. Fashri, Pierre Bourdieu Menyingkap Kuasa Simbol. Yogyakarta: Jalasutra, 2014

[6] Windiani and F. N. Rahmati, "DIMENSI JURNAL SOSIOLOGI," Dimensi, vol. 9, no. 2, pp. 87-92, 2016.

[7] B. dan S. Suyanto, Metode Penelitian Sosial. Jakarta: Kencana Prenada media, 2013.

[8] S. Sempu, "Sistem Informasi Desa Sempu," 2017. 
IPTEK Journal of Proceedings Series No. 6 (2019), ISSN (2354-6026)

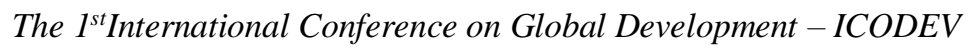

November 19th, 2019, Rectorate Building ITS, Campus Sukolilo, Surabaya, Indonesia

TABLE 1 NATURAL DISASTERS IN KEDIRI REGENCY 2014-2018

\begin{tabular}{|c|c|c|c|c|c|c|c|c|}
\hline \multirow[t]{2}{*}{ Jenis bencana } & \multirow{2}{*}{$\begin{array}{c}\text { Number } \\
\text { of } \\
\text { Disaster }\end{array}$} & \multicolumn{3}{|c|}{ Fatalities } & \multicolumn{4}{|c|}{ Houses } \\
\hline & & $\begin{array}{l}\text { Died and } \\
\text { Diaappeared }\end{array}$ & Injuries & $\begin{array}{l}\text { Suffered and } \\
\text { evacuated }\end{array}$ & $\begin{array}{l}\text { Heavily } \\
\text { Damaged }\end{array}$ & $\begin{array}{l}\text { Moderately } \\
\text { Damaged }\end{array}$ & $\begin{array}{l}\text { Lightly } \\
\text { Damaged }\end{array}$ & Flooded \\
\hline Flood & 3 & 0 & 0 & 5 & 1 & 2 & 4 & 8 \\
\hline Landslides & 13 & 0 & 7 & 66 & 8 & 81 & 11 & 0 \\
\hline Tornado & 13 & 0 & 5 & 179 & 6 & 57 & 332 & 0 \\
\hline Kelud eruption & 1 & 0 & 0 & 39.018 & 8.622 & 0 & 5.426 & 0 \\
\hline Total: & 30 & 0 & 12 & 39.268 & 8.637 & 140 & 5.773 & 8 \\
\hline
\end{tabular}

Sources: Collected and Analysed from Indonesia Disaster Information Data (DIBI), BNPB, 2018

TABEL 2 THE DEMOGRAPHIC DATA

\begin{tabular}{lllcccccc}
\hline \hline No & Sub-village Name & $\begin{array}{c}\text { Name of Sub- } \\
\text { village Head }\end{array}$ & $\begin{array}{c}\text { Number of } \\
\text { RT }\end{array}$ & $\begin{array}{c}\text { Number of } \\
\text { KK }\end{array}$ & $\begin{array}{c}\text { Number of } \\
\text { people }\end{array}$ & Male & Female \\
\hline 1 & Ringinsari & Suwandi & 5 & 308 & 830 & 417 & 413 \\
2 & Sempu & Winarno & 6 & 427 & 1212 & 633 & 579 \\
3 & Sumberpetung & Sumaji & 10 & 537 & 1489 & 741 & 748 \\
& & & $\mathbf{2 1}$ & $\mathbf{1 2 7 2}$ & $\mathbf{3 5 3 1}$ & $\mathbf{1 7 9 1}$ & $\mathbf{1 7 4 0}$ \\
\hline \hline
\end{tabular}

Sources: Collected and Analyzed from SID Sempu, 2017 